\title{
The Underdevelopment of Nigeria and Africa: The Mo' Ibrahim Paradigm
}

\author{
Dr. Etim O. Frank \\ Director, Clement Isong Centre for Development Studies, Faculty of Social Sciences \\ University of Uyo, Akwa Ibom State, Nigeria; Email: okonfetim@uniuyo.edu.ng
}

\section{Doi:10.5901/mjss.2016.v7n2s1p70}

\begin{abstract}
The paper evaluated the rationale why Nigeria and other African states have remained underdeveloped in the presence of huge natural resource endowment, when less endowed States have progressed considerably on the development scale. It adopted the MO Ibrahim leadership and development indices as a measure of human progress and the UNDP reports as the barometer of measurement. The focus was on Nigeria with analytical implication for other African states. Richard Joseph's 'prebendal and patrimonial' framework was used as the analytical perspective. The study revealed that contrary to the alibi that the global capitalism accounted for the slow pace of development in Nigeria and other African states, that 'Asian Tigers' with no natural endowment waded through this same international economic order to attain their current level of development. The absence of 'benevolent leadership, Prebendal and patrimonial politics were identified as part of the causal factors for the lack of development, even where Nigeria and other African state tended to be 'developmental states'. It recommended the benevolent and patriotic dictatorial leadership for Nigeria and African states as a panacea to Prebendalism and the pursuit of the processes of Sustainable Development for Nigeria and Africa. It upheld that the prize monetary reward from the MO Ibrahim foundation should serve as enough incentive for good governance in Africa.
\end{abstract}

Keywords: MO Ibrahim, leadership, Prebends, Patrimony, Underdevelopment

\section{Introduction}

The Mo Ibrahim African Governance rating report, which was released recently, had the Ex-Namibian President Mr. Hifikepuye Pohamba as the winner of the 2014 African leadership award. Some of the indices of governance which the leaders in Africa are assessed include; Safety and the Rule of law; Participation and Human rights; Sustainable Economic Opportunity and Human Development' (Sunday Sun Oct. 23:6). The other indices introduced in 2011 are physical and telecommunications infrastructure; gender; health; welfare services provision; and economic management. The MO Ibrahim prize is the biggest far above the popular Nobel Prize. It is focused on leadership in African States. It is not hasty to state that it is perhaps because the Mo Ibrahim has found out as this study intends to do that leadership deficit has been responsible for African underdevelopment rather than the popularly held view of capitalism and imperialism.

Africa the continent of triple heritage, 'Traditionalism, Islamism and Christianity' is perhaps the richest of the global continents. It is also one of the best endowed in terms of natural resources, but the least endowed in 'quality leadership'. It is also the least developed of all the continents. The underdevelopment of the continent in the face of abundant natural resources gave rise to this study, which sought, in the main to examine and identify the causal variables that could be responsible for decades of stagnation.

In the course of doing this, various explanatory paradigms for the underdevelopment of Africa were evaluated in the application of the method of this paper.

The main purpose of this study was to sketch the kind of evidence, which supports the thesis that the underdevelopment of Africa is largely because of leadership deficit, rather than the development of capitalism and imperialism in the western world. Wherever there had been a seeming leadership in Africa, they had conspired to misgovern the state and give rise to excessive poverty, unemployment, inequality and negate self -reliance.

\section{Africa's Natural Resources}

The endowment of Africa have been estimated to consist of 96 per cent of the World's diamonds, 60 per cent of its gold, 42 per cent of its cobalt, 34 per cent of its bauxite and 28 per cent of its uranium. Africa's Iron reserves are probably twice those of the United States, and its reserves of chrome are the most important by far outside of the former Soviet Union (Mazrui, 1980:71). Africa's wealth in terms of crude oil increases by day. Tanzania discovered crude oil in the shore of 
Zanzibar, Mozambique, Kenya in the East African Rift Valley, Ethiopia and Uganda are already medium term crude oil producers. Nigeria, Ghana, Mali and Tchad(Frank, 2014:90) are all producers of crude oil, that 'powers' the world's economy. It is very instructive to ask, why have not all these translated to the development of the continent and its people?

The global communities have adopted democracy as the most viable political option, which gives vent to the development of man's potential. One of the indices of democracy is 'election' (the formal process of selecting a person for public office or of accepting or rejecting a political proposition by voting). The year 2015 could be described as the year of elections in Africa. In 2015, almost half the states in Africa would go through this process. These include the elections in Nigeria March 28, (which has come and gone, translating power to the opposition) Zambia, January 20, Lesotho February 25, Togo-Benin March 15, Egypt March 21, Sudan, April 2, Mali, April 26, Tanzania, April 4, Ethiopia, May 24; others are Burundi, Burkina Faso, and Cote D'Ivoire(Election in Africa 2015). All democracies must be built on a solid foundation of democratic values and the primacy of the law over those who wielded power. Welfare of the people is in fact a democratic value, and the economy has long been a top priority of practically every government in the world. The preamble of the US Constitution states that one of the principal purposes of the American Republic is to 'promote the general welfare'. The government is expected to stimulate economic growth, widen economic opportunity, alleviate poverty, and provide general welfare benefits as political rights (Sodaro, 2008:177 \&184). These rights if they were to be obtained would have whittled down the high degree of poverty, unemployment, and inequality and increase self-reliance in African states. This certainly, would have been the 'take-off' stage for Africa into development processes. This leads to the statement of the problem

\section{The Problem}

The difficulty of this study was to evaluate the rationale why Africa in spite of her natural and human resource endowment, has been consistently a perennial tortoise in the race for development. The inability to convert these enormous resources into development inputs, which would generate growth and changes, which amount to value addition to the lives of the people, constitute a predicament. The application of these resources was expected in the march towards development to have produced outcomes and impact which would increasingly diminished 'poverty, unemployment, inequality and increase self-reliance' in African States.

The principal issues of this problem included the fact that the continent has more than others in resource endowment, yet the outcomes and impact of development in these climes have never been impressive.

Another structural issue was that, given the abundance of resources as espoused, there are enormous negative outcomes as presented in table I below indicating the out school children against the total population.

Table I. No of out of schoolchildren in comparison to Nigeria

\begin{tabular}{|l|c|c|l|}
\hline Country & \% out of school in million & Est. Population In million & Remark \\
\hline Nigeria & 10.5 & 120 & Very high \\
\hline Pakistan & 5.1 & 185.1 & Went through war \\
\hline Ethiopia & 2.4 & 94.1 & Had drought \\
\hline India & 2.3 & 1.22 billion & \\
\hline Philippines & 1.5 & 98.39 & Had series of natural disasters \\
\hline Cote D'Ivoire & 1.4 & 20.33 & Had war \\
\hline
\end{tabular}

Source: E. O. Frank -The Political Economy of Nigeria's Declining Power in Africa NJLA Vol.6(1) Pp 90-144

The Nigeria's figure was obtained before the Boko Haram insurgence', which has generated enormous cases of Internally Displaced Persons (IDP), which has multiplied the number of people suffering from both poverty, unemployment, inequality, without being able to attend schools. The out of schools children from the affected states run into thousands'. It is instructive to note that most of the countries in comparison to Nigeria have had natural disasters and wars, yet they are ahead of Nigeria in the ratio of in schoolchildren while Nigeria is ahead in the ratio of out of schoolchildren.

Nigeria like most African states presents a graphic case of poverty profile. Data gathered from the National Bureau of Statistics and the Central Bank of Nigeria indicated as shown in table II thus; 
Table II. Nigeria Poverty Ratio and State Population 1999-2008

\begin{tabular}{|l|c|c|}
\hline State & \% Incident of Poverty & Population 2006 Est. \\
\hline Jigawa & 95 & $4,348,649$ \\
\hline Kebbi & 98.7 & $3,238,628$ \\
\hline Kogi & 87 & $3,278,487$ \\
\hline Bauchi & 86.3 & $4,676,465$ \\
\hline Kwara & 85.2 & $2,371,089$ \\
\hline Yobe & 83.3 & $2,321,591$ \\
\hline Zamfara & 80.9 & $3,259,846$ \\
\hline Gombe & 77 & $2,353,879$ \\
\hline Sokoto & 77 & $3,696,999$ \\
\hline Edo & 33.1 & $3,218,332$ \\
\hline Osun & 32.4 & $3,423,535$ \\
\hline Enugu & 31.1 & $3,257,298$ \\
\hline Rivers & 29.1 & $5,185,400$ \\
\hline
\end{tabular}

Source: E.O. Frank, Poverty Eradication in Nigeria-Problems and Prospects (AJPAS) VOL.4(1) Sept,2008 p 61

Table II is very instructive; it indicated the incidence of poverty against the total population. The calculation shows a huge per cent of the population in poverty, which is an indication of failure to manage the monthly-allocated federation account judiciously, not to mention the internally generated revenue.

It indicate failure of quality leadership from 1999 for the period leading to the year 2008.

On the continental level, Zambia, Malawi and Zimbabwe are studies in political and economic regression. In Ethiopia, the previous revolutionaries now in government have become reactionaries killing protesting students after rigged elections. Somalia has the 'distinction' of being the first State to disappear as a political entity in the World. Tchad's Idris Derby refused to hand over power. In Nigeria, its 170 million people are poorly served by a conniving and corrupt regime at all levels (Osuntokun, 2015: 19) of elite' conspiracy.

\section{Explaining the African Conditions}

It is instructive to note that yet another issue, the dominant paradigm for explaining African underdevelopment. Scholars such as the late Ali Mazrui averred that the 'pathologies of technical backwardness, mal-distribution and of fragmented economies (Mazrui, 1980:70-71) are accountable. These triple pathologies have resulted in enormous poverty of the people and the continent. The consequence of the mal-distribution of the available resources ignited the 'Arab Spring'. It is instructive to note that relative social deprivation creates social discontent whose consequences could be unimaginable. Fragmented meant that African economies could not take advantage of the economy of scale they are also not taking advantage of regional economic groupings. Trade between African States are the lowest. These jointly accounted for the underdevelopment of the African continent despite the available natural resources.

Andre Gunder Frank, on the other hand, posited in his theory of 'Development and Underdevelopment' that the capitalist development of the western societies, simultaneously led to the underdevelopment of Latin America and by extension Africa. The new form of this is captured in the practice of 'Imperialism' (Frank, 1969: 17-31). The approach created satellite -metropole relationship where goods are taken from one in an unequal term of trade, and use in the development of the other. This explanatory paradigm failed to explain why African states have not taken advantage of several decades of independence to achieve significant liberation of its citizenry out of the morass of poverty, unemployment, inequality and achieve self-reliance. This again explained away as being caused by imperialism. Nevertheless, someone has to take a decision-leadership.

W. W. Rostow's, 'The Stages of Economic Growth' posited that there are five linear stages of economic progression namely; (i) the traditional society- where production is limited because of insufficient technology, (ii) the preconditions for take-off- where there is a sector in the economy doing well, which influences the growth of other sectors in the economy. Agricultural output increased and is used to support other sectors.(iii)The take-off, here old values that are resistant to change are removed, all sectors of the economy grow. Investment and saving increases in relations to the Gross Domestic Product. There is institutional development in the society (iv) The Drive to maturity - there is sustained growth, 10-20 percent of national income are invested. New sector of the economy emerged to support the old ones. (v) The Age of mass consumption- consumers goods are produced in large quantity (Henriot, 1976: 7). E. F. Schumacher 
called the age of 'technostructure' of this age. Out of these five linear stages, most of African States have not been able to go beyond the first two stages. It explained that the dominance of cultural values, lack of the adoption of modernization, absence of achievement drive and the internal obstacles factor, accounted for the situation in Africa. The explications of the African conditions constitute part of the problem of this study because they have failed to satisfy the curiosity of many.

The frustration with African development led the developed nations to have designed eight (8) development goals christened the Millennium Development Goals (MDGs) for the developing societies. It is very probable that no African State would score about 50 percent attainment of the goals by 2015. Africa realising the frustration with her development strides, created for itself the New Partnership for African Development (NEPAD). There has been neither partnership nor Development. The African Peer Review Mechanism (APRM) that was supposed to ensure leaders abide by constitutional rules and achieve the goals of NEPAD has been ignored (Osuntokun 2015). It is instructive to note that the elites in governance in African States defined 'Development' as growth in the Gross Domestic Product (GDP). This is the reason why in many States, where growth had led to greater GDP, the outcomes and impact on the lives of the citizenry had been greater poverty, unemployment, increasing inequality and depreciating chances of self-reliance. The continent has seen more wars than any other has. These issues in the view of this study have not addressed the principal cause of African underdevelopment. These explications have not revealed the causal variables of Africa's underdevelopment. However, the trouble with Nigeria is simply and squarely a failure of leadership (Achebe, 1998:1). MO Ibrahim organization came to this realization and instituted the most prestigious prize for quality leadership, yet Prebendalism seems to have taken over the mindset of Nigerian and other African leaders.

\section{Framework of Analysis: Prebendalism and Patrimony}

The theoretical framework of analysis which would present the explanation for the probable underdevelopment, which confronts Africa as a continent and Nigeria as a state, would be better appreciated from the perspective crafted by Richard Joseph in his seminal work 'Democracy and Prebendal Politics in Nigeria: The Rise and fall of the Second Republic (1987)', he posited that the 'trouble with Nigeria was the Prebendal Politics and Patrimonial governance. According to the theory of Prebendalism, state offices are regarded as prebends (instruments) that can be appropriated by the office holders, who use them to generate materials benefits for themselves and their constituents and kin groups(Joseph, 1987:67). This refers to the sense of entitlement to national resources or treasury which Nigerian elites conjure in the plundering of national resources to personal use and in favour of their ethnic groups and favoured friends. In this context, elected officials, government workers, and other power wielders, feel it is their chance to evoke primitive accumulation (pillage) of the public wealth for personal and group advantage, outside the established processes and procedures for acquiring wealth. As a result, planning economic development for all was ignored for planning for self. The consequence of this approach to development is often massive poverty, unemployment and depreciating Human Development Index (HDI).

Consequent upon this, there has always been 'arrested development' (Corruption) of resources appropriated for development and other social interventions from the Medium Term Expenditure Framework (MTEF). When the resources are primitively accumulated, the outcomes are often greater degree of poverty, unemployment, inequality and lesser probability of self-reliance, in short lack of service delivery.

Prebendalism everywhere begat Patrimonial form of governance in which all power flows directly from the 'prebendal leader' (that is, the manipulator of the system to favour himself and his ethnic groups), irrespective of the existence of the principles of separation of powers. This is the principal character of African politics and specifically of Nigeria. This explains the rationale behind the recent appointments of the Nigeria President (Muhammed Buhari, of 31 principal appointments, only 7 come from the Southern Nigeria).

One major characteristic of patrimonial politics is the closeness of both the private and the public sector (a situation in which, in the absence of the leader, everything is stalled). The governance system assumed both autocratic and oligarchic forms. This was and is still found everywhere in Africa with few exceptions. This form of politics and governance are prevalent in Africa and gave rise to the continuation of the development of underdevelopment after several decades of independence. Stolen funds are stacked in foreign banks. To this extent, the lack of leadership in Africa account for the pathology of underdevelopment.

\section{The Method of the Study}

It is instructive to state that the scope of this study was the entire Africa with focus on the fifty-four (54) sovereign states in 
Africa. This presented a huge research problem. A purpose sampling technique was adopted which entailed a deliberate choice of the sample units to ensure their near exact proportionate representation of the entire population out of the universe of fifty- four nation-states.

Data was drawn from Nigeria with cross references to some other countries for the analysis thereof as presented. This was applied across the continent with a very slide (0-05) margin of error.

The methodology measure of this study was descriptive, designed to obtain information concerning the status of African development. Its essential focus was to determine the nature of the situation as it existed at the time of the study with respect to the variables of the situation. In its application, the 'MO

Ibrahim leadership and development indices were examined across Africa with the intention of finding which country met them, with emphasis on Nigeria in West, Egypt in the North, Zimbabwe in the East and post-Mandela South Africa in the South. All these with 0-05 margin of error. This was done to generate inferences for the complete universeAfrican states by examining a part of it.

The processes consisted of examining these states against the MO Ibrahim indices of leadership and development.

\section{Mo Ibrahim Framework}

It is the main theses of this study that the explanatory paradigms ranging from the Mazrui's 'pathologies of the African conditions' through the thesis of Andre Gundre Frank's 'Development of Underdevelopment' to the Rostowian 'Stages of Development' have failed to conceptually explicate the lack of development in Africa ala Nigeria since independence. This is because, the 'Asian Miracle States' also experienced colonialism and Imperialism, sometimes worst type than African states did, yet they belonged to the group of States that are making progress as Atul Kohli has stated. Quite perplexing is that the Asian States such as Singapore, charted the course of its development within the same global capitalist system. What was found to be common in those states that are making economic progress, is what perhaps the Mo Ibrahim Foundation found out and instituted the leadership price in Africa, this is 'Leadership deficit' in African development.

It was in recognition of this deficit, that the Mo Ibrahim foundation instituted the greatest prize in the World far above the Nobel Prize to encourage the evolution of quality leadership in Africa.

The Mo Ibrahim Foundation was launched in October 2006 to support good governance and great leadership in Africa (the foundation was appalled that in spite of the abundance of natural capital, Africa's development indices were negative in all indices of Human Development). Its goals are to (i) Provide a framework and tools with which citizens and governments can assess and measure progress in governance (ii) Recognize excellence in African leadership and provide a practical way in which leaders can build positive legacies on the continent when they have left national office (iii) Stimulate debate on the quality of governance and major governance issues in Africa (iv) Develop leadership and governance capacity in Africa(www.Mo Ibrahim.org). The prize is US $\$ 5$ million initial payment, plus $\$ 200,000$ a year for life, the prize is believed to be the world's largest, exceeding the $\$ 1.3 \mathrm{~m}$ Nobel Peace Prize(www. Mo lbrahim.org).

\section{Ibrahim Index of African Governance}

The Ibrahim Index assesses African countries based on the quality of their governance. Countries are graded on factors, which fall into;

i) Democratically elected former African Heads of State who have delivered

ii) Security, health, education, rights, rule of law and economic

iii) Who have democratically transferred power to their successors in the last three years?

iv) Good governance is crucial.

v) Participation and Human Rights,

vi) Sustainable Economic Opportunity and Human Development.(www.Mo Ibrahim).

The focus of this study coalesce with that of Mo Ibrahim foundation in that the missing link in Nigeria and Africa's development is the absence of leadership rather than the development of capitalism. It is informative that we get to know the content of the concept of 'leadership' in order to evaluate why its emergence in Africa nay Nigeria to drive development has proven so difficult. 


\section{Data Presentation}

Nigeria (i) on the first Mo Ibrahim index, democracy, Nigeria had been under military dictatorship for several years. It returned to democracy in 1999 and there have been no corresponding upward improvement in the standard of living of Nigerians. The National Bureau of Statistics Report (2012), indicated that more Nigerians are into the poverty bracket since 1999 (date of return to civil rule) than they were before this date (Frank, and Odigie, 2012: 98).

ii) The 2013/14 Human Development Report ranked Nigeria in the 152 position within the category of Low Human Development countries, with 0.504 and 0.004 differences between 2013/2014. This means Nigeria was declining on the scale. Kenya, Swaziland, Angola, Rwanda and Cameroon ranked 147-152 positions respectively ahead of Nigeria (UNDP-HDI 2013-14).

iii) The Human Development Report (2004) had ranked Nigeria 1515t out of 177 countries in the world. Ten (10) years later Nigeria could only manage to move (3) three notches downward instead of upward. It indicated a deteriorating socio-economic policies and failing political leadership.

iii) The International Monetary Fund (IMF) in its 2010 listing of countries according to Purchasing Power Parity (PPP), placed Nigeria in the $140^{\text {th }}$ position out of 182 nations, with an average per capita income of US $\exists 2,398$. The value of its output of goods and services is too small for its human and natural resources endowment. The countries at the top of the IMF's list have no natural resources compare to Nigeria (Frank \& Odigie, 2012:98).

iv) The Mo Ibrahim African Governance Rating Report ranked Nigeria $41^{\text {st }}$ out of 53 countries excluding the Republic of South Sudan) in 2010 out of 48 countries ranked, Nigeria was $40^{\text {th }}$ and $35^{\text {th }}$ in 2009 and $39^{\text {th }}$ in 2008 . In West African sub-region, Ghana was rated first and $7^{\text {th }}$ in Africa, while Nigeria maintained the $13^{\text {th }}$ position in West Africa, the same rank it got in 2010. The assessment indices were; governance, Safety and Rule of law, Participation and Human Rights, Sustainable Economic opportunity and Human Development (Editorial Sunday Sun 2011:6).

v) Comparatively; UNICEF had ranked Nigeria as being the $14^{\text {th }}$ highest Under-Five Mortality Rate (U5MR) in the world, Ghana, Benin Republic and Togo were ahead of Nigeria on this ranking. According to the Report, U5MR in Nigeria was 201 per 1000 children in 1990. Ghana 30.5 per 1000. The current rate for Nigeria stands at 194 per 1000. It needed to be reduced to 77 by 2015, to meet the $4^{\text {th }}$ Millennium Development Goal (MDGs) target. (Frank, 2007:154).

vi) Egypt; by the 2013-estimated population stands at 82.06 million people. In terms of human security, the yearning for this was partly responsible for the 'Arab spring'. It has been alleged that human security is very weak currently in Egypt as there are many social groups including the orthodox Christian group, Muslim brotherhood and many others. In relations to health policy, Egypt has 58 per cent of the population on the Health Insurance Organization (HIO), however the menace of hepatitis, tuberculosis continue to pose a great challenge to the people. Educationally, Egypt is doing better than any other country in the Middle East with free and compulsory public education system spanning from the kindergarten to the tertiary level.

On Civil Rights, the 'Freedom House' had rated Egypt as being not a free state in terms of press freedom (Aljazeera journalists are currently in jail). It has been submitted that whatever must have been achieved in time past has been reversed under the current regime. On the rule of law, it is strong on paper and shakier on the ground (Eldakak, 2012). Egypt however on human development index, belongs to the medium development category with an unemployment rate of 13.3 per cent in 2010 with about 22 million people living in poverty. According to the United Nations Food Agency and its partners, Egypt has been experiencing a rise in poverty and food security for the past three years, while unemployment rate had almost double to 24.2 per cent. According to CAPMAS, 26 per cent live in poverty while 49 per cent of the upper class cannot provide for basic needs such as food. In spite its record of accomplishment, Egypt has not been able to meet the MO Ibrahim criteria.

vii) Zimbabwe: Zimbabwe's Human Development Indices (HDI) value for 2012 stood at 0.397 and belongs to the low human development category-positioning the country at 172 out of 187 countries and territories. Life expectancy stood at 59.5 According to Jeni Klugman, (2010) director of the Human Development Report UNDP, Zimbabwe has the worst quality of life in the world, according to the United Nations human development index. The 15 worst-off countries are all Africa. Poverty and unemployment are both endemic in Zimbabwe, driven by the shrinking economy and hyperinflation. Poverty rates run near $80 \%$, while the unemployed is ranked as the world's largest, at $95 \%$ (www.zimbbawe)

Rule of Law - Zimbabwe is upheld in breech where the 'green beret' the armed youth group (propagating the ideals of Mugabe) are use to intimidate citizens where the military forces are not in use. In Zimbabwe, the rule of law has been, "mutilated," according to Beatrice Mtetwa, the country's Constitution had been amended 17 times, laws are selectively interpreted depending on one's political affiliation, and judges often rule to support the agenda of Zanu-PF, Robert Mugabe's ruling party. Human rights abuses are rampant and often occur without consequence (www.zimbabwe.org). In 
the absence of democracy, there can be no development. The flight of democracy in Zimbabwe reverses all other indicators of development. The cumulative effect of the political situation in Zimbabwe is that it does not ever get closer to meeting any of the MO Ibrahim variables for leadership.

viii) South Africa: South Africa has 52 million people as at 2013 estimate. According to the South African statistical bureau, Poverty levels in South Africa currently stands at year 2011, level at a low of $20.2 \%$ for extreme poverty and of $45.5 \%$ for moderate poverty. Of this 12 million, live in abject poverty while unemployment and inequality are the other challenges confronting the political leadership (www.southafrica.org).

\section{Analysis and Outcomes}

The variables discernible from the data generated in this study included; leadership from the high performing Asian States, prevalent in African States are 'prebendal and patrimonial policies and politics. Lack of good governance, patriotism and the absence of the processes of Sustainable development, are the major characteristics of public policies in Nigeria and Africa. These are discussed herein.

Nigeria was examined under the following rubrics;

i) Economic Development policies: It subscribed to a state-directed system to promote development rapidly and equitably than would free-market capitalism. This was because in the emerging post-colonial states, very few people had initial capital to finance development projects. This led to the creation of several State Owned Enterprises (SOEs) such as; National Electric Power Authority (NEPA), Nigeria National Petroleum Corporation (NNPC), Nigeria Railway corporation (NRC), Nigerian Airways, and Nigeria National Shipping Line (NNSL) etc. However, it was found out that this did not lead to any form of development because of the increasing gaps in poverty, unemployment and inequality in comparative terms. Nevertheless, in South Korea, Malaysia and Singapore, the same policy thrust led to significant development. It indicated that there was a missing link in the way Nigeria and African States managed their affairs.

In a study conducted by Atul Kohl (cited in Sodaro, 2008:374), State Owned Enterprises were effective in Coherent-capitalist states like South Korea and the Asian tigers. They were characterized by a cohesive 'rational-legal' central state and a clear distinction between the public (State) and private enterprise. This tended to be more successful because they were able to organize and carry out coherent government programs, which stimulated vigorously the private sector development (Sodaro, 2008:374). This was not to be in Nigeria (African States). This study, was interested to understand what caused the coherency in policy implementation, which resulted into development in these states

Kohl also identified another set, Fragmented-multiclass states such as Brazil and India which are often better organized with the states authority tending to be fragmented because it rests on a very diverse society and its attendant political alliances. These patterns of states often find it difficult to pursue a coherent, focused development strategy because they must meet the demands of multiple social and political groups simultaneously. In order to satisfy their supporters they spread the resources over series of conflicting goals (promoting industrial growth, subsidizing agriculture, redistribution of wealth to the poor).

The third category of states was the 'patrimonial states, typified by Nigeria. This pattern features government officials who regard public resources such as the national treasury and other state assets as their own personal patrimony, to be plundered for their own benefit or for the benefit of their favoured group. Patrimonial states tend to do poorly in promoting economic development.

It is instructive to note that Nigeria in this context typified most African states.

Again, why does other perform better on the economic development than Nigeria?

\section{Towards the Leadership Fault-line in Africa}

i)Mou and Nwabuzor averred that leadership simply means 'purposive effort by an individual or group of individuals to direct the energies and behaviour of others towards the achievement of common objectives (Mou,2014:93). Akinkuowo, on his part posited that the concept of a leader evoke 'authority to take initiative and go ahead of others. A leader then is entrusted with (i) 'crafting out a vision for the rest of the relationship with followers. (ii) A leader has the responsibility to ensure that a vision is drawn out and pursued with a sense of purpose, discipline and commitment (ii) the other elements of leadership include giving direction, coordinating people, providing the motivation to move the society to its destination(Akinkuowo, 2013: 128).

David-West's submission on this was that, a leader must have a vision of the future, Leadership is the pivotal force behind successful organizations, it is a trust and therefore accountable to the people. Maxwell, leadership determines the success, while vision determines the direction of the organization. It is influence earned when you serve people selflessly, 
it entails sacrifice. The summary of all these is that the success of a state as an organization depends on leadership (cited Frank 2012; 94). It follows logically that the lack of development in Nigeria and Africa indicated the absence of leadership rather than growth of capitalism and imperialism.

Leadership would have shown the way to go and how to manage the available natural capital for the benefit of all appeared in the two categories of states identified by Atul Kohli. Leadership that is patriotic would have addressed the pathologies, stages of growth as Lee Kwan Yew did in Singapore and others did in Korea and Malaysia respectively by being patriotic, disciplined and many times benevolent dictators.

The underdevelopment of Nigeria and African States in the face of enormous natural capital many of which are used by the entire world indicate leadership deficit in economic thinking. Where there is leadership deficit, the vacuum is usually replaced by 'Prebendal politics and patrimonial administration as typified by Nigeria.

ii) Patrimonialism manifested itself in different manners thus; (a) the National Integrated Power Project (NIPP) had $\$ 16$ billion dollars spent on it, it is instructive to note that most of these expenditure were made to companies unknown to the Corporate Affairs Commission (CAC). At this point, the 'Due Process' bureau had come into existence yet the transaction to non-existing companies went through. (b) There was the intention to improve air transportation in Nigeria; hence, the Minister of Aviation was permitted to source funds for the improvement of airports in the Country. 6.5 billion Naira was sourced through the Zenith Bank PLC. The President, who came after Obasanjo, was said to be furious with the roles of the former president, Borishade and Fani-Kayode in the disappearance of the funds. (c) According to Farida Waziri the former chairperson of the EFCC, about three trillion Naira were received by the 774 local government councils in the country between 1999-2007, yet there were nothing to show for these huge investments funds.

(d) The United Nations Industrial Development Organization (UNIDO) in its 2004 report after extensive survey of the economic and social conditions of nations in Sub-Saharan Africa, singled out Nigeria as the worst case of capital flight in the region, with more than $\$ 100$ billion private wealth kept abroad...Nigerians according to the report are poorer today than they were 20 years ago...unless this is redressed the drive to attract foreign investments to Nigeria will be meaningless, UNIDO had warned (Frank, 2008: 4)

iii) Resource Curse and Conflict- The use of natural resources in Africa because of the consistent inability of political leaders to turn natural resources to advantage have led many to assume that the natural resource is a curse rather than a blessing. The scenario is the natural resources in the African continent wherever found would be in the territory of the minority ethnic groups, while political power would be in the hands of the 'majority' ethnic groups. Often the majority ethnic groups use the resources to the exclusion of the minority ethnic groups (lack of good governance).

The continuous exclusion of the minority groups and their agitations for inclusion in governance, particularly in relations to the use of the resources, account for about 90 per cent of conflict in the continent. This (these) account for all the post independence conflict in Africa and the civil war in Nigeria 1967-70 and the militancy in the 1999-2011. It is the governance system which excludes the 'minorities' in whose territories the natural resources of the state are located, which accounted for the several upsurge of instabilities, violence and the numerous civil wars in Africa. These are some of the ways in which the Nigerian and the African ruling class at large have thwarted the development of the state and that of the continent and have continuously arrested the march to development freedom.

iv) In the year 2000, out of the 34 countries classified by the World Bank as being severely indebted countries in the world, 28 were in Africa. This type of incongruence between the available natural resources and the manifest development level of the continent indicated a missing link in the development equation of the continent.

vi) The inability to harness the available resources to generate development in Nigeria and indeed Africa is manifest in the current life expectancy database released by the WHO. Life expectancy at birth for the average Nigerian is about 51 years. This compares unfavourably with other countries such as Sri Lanka 71, Hong Kong 78, United States 76, Portugal 75, and Greece 77, Japan 79, and Canada 77, years... these are made up of variables such as achievement of better nourishment, shelter, health, education, living condition and better conditions of employment for low-end poverty groups (Nyong, 2005:15). What this meant is that the objective living conditions of Nigerians have not been improved in order to give them longer life expectancy on earth. It is a function of the use of the available resources.

\section{Conclusion}

The underdevelopment of Africa must have been started by the slave trade and colonial episodes. However, independence came and after fifty (50) years of statehood, African States and indeed Nigeria have remained underdeveloped in all sectors of Human Development Index simply because of leadership deficit rather than the lack of capital, lack of entrepreneurial ethos and the spirit of capitalism and North -South dichotomy cliché. The analysis indicated a reflection of the quality of leadership prevalent in Nigeria since independence. 
The Asian Tigers, which moved ahead, had very similar socio-political history as Nigeria and many other African States. They moved from the Prebendal and Patrimonial stage of development through the prevalence of benevolent dictatorship (Lee Kuan Yew -Singapore, Park Chung-Hee-South Korea) they all had 'New Deal' for their economies. African Leaders and Nigeria deserve such an initiative that is compatible with the time to look forward. Dictators in Africa are neither benevolent nor patriotic but self-destructive.

It is enlightening at this point to clarify the concept of benevolent dictatorship, it signifies the idea that a political leader is needed to take charge of the battle against underdevelopment rather than become its agent. He is to stage a fight against economic depression in the same manner in which Park Chung-Hee launched the miracle of the 'Han River' and heavy industries initiatives and Lee Kuan Yew set up the processes of Sustainable Development.

Nigeria and indeed Africa must take the destiny of the continent in their hands and produce a benevolent dictator to drive the processes of development, without waiting for foreign aid, which often come with strings attached to it.

The question remains where to find and how to create these benevolent dictators in Africa. Nevertheless, this is what Africa requires to move out of Prebendal politics and patrimonial governance.

It is instructive to note that former Presidents Joaquim Chisanno (Mozambique) and the late Nelson Mandela (South Africa) were the laureates in 2007, Festus Mogae (Botswana) in 2008, Pedro Pires (Cape Verde) in 2011 and Hifekepunye Pohamba in 2014, while there were no laureate in 2009, 2012, 2013. Nigerian and indeed African leaders should take advantage the greatest global prize in governance and deliver good governance.

\section{References}

Achebe, C. (1998). The Trouble with Nigeria. Enugu: Fourth Dimension Publishing Co. Ltd

Akinkuowo, E. (2013). Between Vision and its Manifestation. In Him Resources: Lagos

Beatrice Mtetwa (2013). 'The Rule of Law Documentary Film Project 2013 www.zimbabwe.org

Editorial (Sunday Sun, 201, Oct 23), 'Nigeria and MO Ibrahim Governance Index' Sunday Sun Newspaper, October 23, 2011 p. 6

Eldakak, A. (2012). Approaching Rule of Law in Post-Revolution Egypt' UC Davis Journal of International Law and Policy 18:2 (2012) 261-307

Frank, A. G. (1969). Latin America: Underdevelopment or Revolution. NY: Monthly Review, cited in Daniel A. Offiong (1980) Imperialism and Dependency. Enugu: Fourth Dimension Publishing Co Ltd.

Frank, E. O. (2007). Nigeria and Ghana: A Comparative Study in Governance and Development. International Journal of Social Sciences-Faculty of Social Sciences, University of Uyo, June Vol. 6(1) pp 154-165

Frank, E. O.(2008). Poverty Eradication in Nigeria: Problems and Prospects- African Journal of Political and Administrative Studies (AJPAS) a publication of Ebonyi State University Vol.4 (1) Sept 2008 pp 53-73

Frank, E. O. (2008). The Nigerian State in the Stage of Primitive Accumulation-The International Researcher Vol. 1(2) pp 4 -12

Frank, E. O. and Odigie, S.A. (2012). Leadership, Policy Effectiveness and Development in Africa -International Journal of Social Sciences-Faculty of Social Sciences, University of Uyo, Vol. 8(1) April, pp 87-102

Frank, E. O. (2014, Jan-June). The Political Economy of Nigeria's Declining Power in Africa: Outcomes and Policy Options, Nigerian Journal of Legislative Affairs, Vol. 6(1) pp 90-114

Henriot, P. J.(1976) Development Alternatives: Problems, Strategies, Values-occassional Population Papers series of cultural Values and Population Policy Project, Jan. 1976, Institute of Society, Ethics and the Life Sciences, Hastings-Hudson, N.Y 10706 http://works.bepress.com/ahmed-Eldakak CAPMAS- Egypt Central Agency for Public Mobilization and Statistics 2015

Joseph, R. A. (1987). Democracy and Prebendal Politics in Nigeria; The Rise and Fall of the Second Republic USA: Cambridge

Kohl, A. (2008) State-Directed Development: Political Power and Industrialization' cited in Sodaro, M. J. (Ed). (2008) Comparative Politics- A Global Introduction NJ: McGraw-Hill Higher Education

Klugman, J. (2010). United Nations Development Programme Report 04/11/2010

Mazrui, A. A. (1980). The BBC-Reith Lecture Series- The African Condition. London: Heinemann Books.

Mou, D. (2014, Oct 21). 'Youths and Leadership in Emerging Democracies'-The Guardian Newspaper, Tuesday, October 21 p 93

Nyong, M.O.(2005). Public Policy, Public Sector Economics and Management in Nigeria. A \& A Communication: Calabar

Osuntokun, J. (2015, March 4). 'The African Condition 2'. The Nation Newspaper March 4, 2015 pp 19

Sodaro, M. J. Collinwood, D. W. and Klesner, J. L. Sisk, T.D.(Ed) (2008) Comparative Politics- A Global Introduction. N.Y: McGraw-Hill Higher Education

The Sunday Sun Newspaper, Oct. 23, 2011 p. 6

United Nations Human Development Report 2014 NY: OUP

www.all elections in Africa 2015 (accessed Oct. 3, 2015).

www.Mo Ibrahim.org (accessed Oct. 3,2015) 